discussion will bring modern conservation biology to bear on CITES, something that has so far happened only to a "very limited" extent.

Mace also believes that CITES needs to go beyond whether a species is endangered and take into account the effect of trade on wild populations. Many endangered species are not threatened by international trade, she says, while other species that are not yet endangered are declining rapidly as a result of trade.

The southern African countries are also trying to score political points over their opponents from the developed world. One audacious proposal is for the Atlantic herring to be placed in Appendix 1 of CITES, a move that would make international outlaws of many European fishermen.

James Martin Jones, from the World Wide Fund for Nature (WWF) says the herring is now recovering from the overfishing of the 1970 s, so that any such proposal should be defeated easily. But "had they gone for haddock or even cod, they could have made a strong case," he says. Nevertheless, the underlying message of the southern African countries is clear: countries that have no elephant populations of their own should not be laying down the rules for elephant conservation.

Few observers are willing to predict the outcome of the vote in Kyoto on southern Africa's elephant populations. But if all of Africa can come to a consensus, the developed world is expected to agree with its line.

Peter Aldhous

ANIMAL RESEARCH

\section{Importer indicted}

\section{Washington}

MATTHEW Block, president of Miami-based Worldwide Primate, a major US importer of research primates, was indicted last week by a federal grand jury for violating the Endangered Species Act. In the fourcount indictment, the grand jury charged Block with attempting to ship six baby orangutans out of Bangkok, Thailand.

Orangutans are an endangered species and may not be sold or transported without a special licence. According to a statement released by the US Attorney for the Southern District of Florida, most of the smuggled orangutans, which were labelled as birds, "succumbed to the stress of their captivity and poor handling" despite an international effort to save them after they were intercepted by Thai authorities in 1990. If convicted on all counts, Block faces up to 12 years in prison and $\$ 700,000$ in fines.

Last year, Block sued Shirley McGreal, chairwoman of the International Primate Protection League, claiming that she had damaged his reputation in the course of helping the US authorities. That case is still pending. Christopher Anderson

\title{
Warning on population growth
}

\section{London}

THE US National Academy of Sciences and the Royal Society of London have this week published a joint statement on present global problems that gives central attention to world population growth. Among other things, the statement calls for an inter-academy conference, likely to be held in Sweden next year.

Although the frequent US reports by the National Research Council are technically opinions to which the council of the US academy assents, the Royal Society has traditionally been shy of committing itself to opinions on public policy, citing the difficulty of reaching agreement within its council. The joint statement is claimed to be an occasion without precedent.

This is also the first time the two academies have issued a joint statement on a matter of general interest, reflecting (the statement says) joint "deep concern". The statement took two years to write, and was completed only a few weeks ago. A visit last year to London by Carl Djerassi appears to have helped powerfully to crystallize the text now published.

Next year's conference will be organized by the Royal Swedish Academy of Sciences, and will probably be held in the spring. Other academies worldwide are being invited to act as co-sponsors.

The declaration links the estimated growth of the world's population of 100 million a year with the way in which human activities are producing "major changes in the global environment". If growth remains unchecked, and the patterns of human activity unchanged, according to the statement, "science and technology may not be able to prevent either irreversible degradation of the environment or continued poverty for much of the world".

Population estimates are based on the 1991 report of the UN Population Fund, which noted an acceleration of population growth since 1984. Even assuming sustained decreases of fertility towards the replacement level of 2.1 offspring per woman per lifetime, the statement says that world population may be 10,500 million in 2050 , close on 90 per cent of it in developing countries.

The two academies argue that both developed and developing countries add to the pressure on the environment. Developed countries, with 85 per cent of the world's gross national product, account for most resource consumption; their emission of carbon dioxide "has the potential for altering global climate", with global consequences. Although resource consumption per head is lower in developing countries, the pressure of population and for economic growth may have similar consequences.

Present patterns of activity coupled with population growth, the statement says, should make "even those most optimistic about future scientific progress pause". It says that some environmental changes may irreversibly damage the Earth's capacity to sustain life, noting that many species have already disappeared or are likely to do so.

The academies go on to urge that this year's UN Conference on Environment and Development should acknowledge that both human activities and population growth are essential to a consideration of a sustainable world society. They urge more "effective family planning", coupled with economic and social change, for the developing countries, and conservation, recycling, substitution and the more efficient use of energy for industrialized states. Mitigating carbon dioxide emissions is an immediate goal.

Turning to how science can mitigate these problems, the academies back (in order) "new generations of contraceptives", alternative energy sources, improved agriculture, animal and plant genetics, biotechnology and public health (including vaccines against infections such as malaria and AIDS).

Biodiversity gets a special commendation. The statement says it is important that the "nature and dimension" of the world's biodiversity should be understood. But the present rate at which species are disappearing is the greatest in 65 million years (since the Cretaceous-Tertiary extinction). The "loss of biodiversity ... . is irreversible ... and has serious consequences for the human prospect in the future".

The statement also warns that people should not expect too much from science. It says that while research and innovation can mitigate many of the world's problems, "it is not prudent to rely on science and technology alone to solve problems created by rapid population growth, wasteful resource consumption and harmful human practices".

The statement refers to most of the issues now conspicuous on the agenda of environmentalists, some of which are controversial. But it stops short of seriously contentious questions, such as the policy of the US government on the provision of overseas aid linked with abortion and the position of the Roman Catholic Church.

More generally, the statement concludes with a commendation of "global policies ... to promote more rapid economic development throughout the world, more environmentally benign patterns of human activity and a more rapid stabilization of world population".

John Maddox 